Section Editor

Mitchell S.V. Elkind,

MD, MS
Teaching NeuroImages:

\section{Intracranial dural arteriovenous fistula presenting as ascending paralysis}

Waldo R. Guerrero, MD*

Haitham Dababneh, $\mathrm{MD}^{*}$

James Cook, MD

Keith R. Peters, MD

Correspondence \& reprint requests to Dr. Guerrero:

waldo.guerrero@neurology.ufl.edu

Figure 1 Sagittal MRI
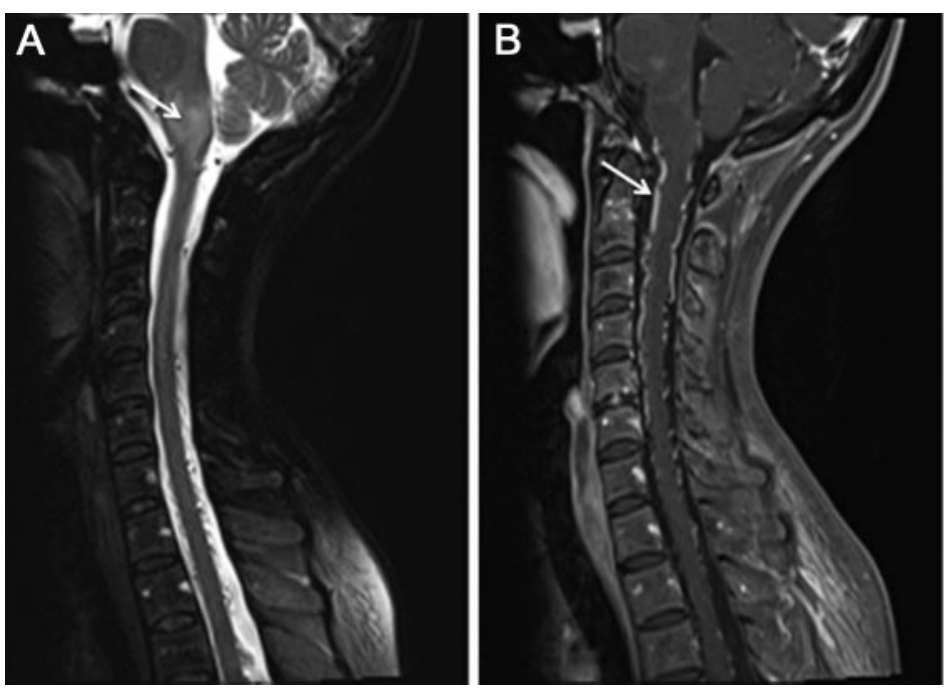

T2 MRI (A), hyperintensities in the medulla and cervical cord. T1 with gadolinium (B) shows dilated epidural venous plexus.

A 50-year-old woman presented with 4 weeks of ascending paralysis associated with nausea, vomiting, hypophonia, and dyspnea. Examination revealed hypophonia, diminished strength in the upper and lower extremities, increased reflexes throughout, and a T10 sensory level. Imaging (figures 1 and 2) demonstrated an intracranial dural arteriovenous fistula (DAVF) with spinal drainage.

DAVFs represent an acquired abnormal communication between arterial and venous channels within the dura and produce the dilated tortuous veins with resultant venous hypertension. The venous drainage of intracranial arteriovenous fistulas is usually into intracranial veins; however, this case highlights the potential for drainage into the spinal region, which can cause progressive myelopathy. ${ }^{1,2}$

\section{AUTHOR CONTRIBUTIONS}

W. Guerrero: author, organization, image collection. H. Dababneh: author, organization, image collection. J. Cook: author, supervisor. K. Peters: figure author, interpretation of angiogram and MRI, supervisor.

\section{REFERENCES}

1. Asakawa H, Yanaka K, Fujita K. Intracranial dural arteriovenous fistula showing diffuse MR enhancement of the spinal cord: case report and review of literature. Surg Neurol 2002;58:251-257.

2. Wiesmann M, Padovan CS, Pfister HW, Yousry TA. Intracranial dural arteriovenous fistula with spinal medullary venous drainage. Eur Radiol 2000;10:1606-1609. 


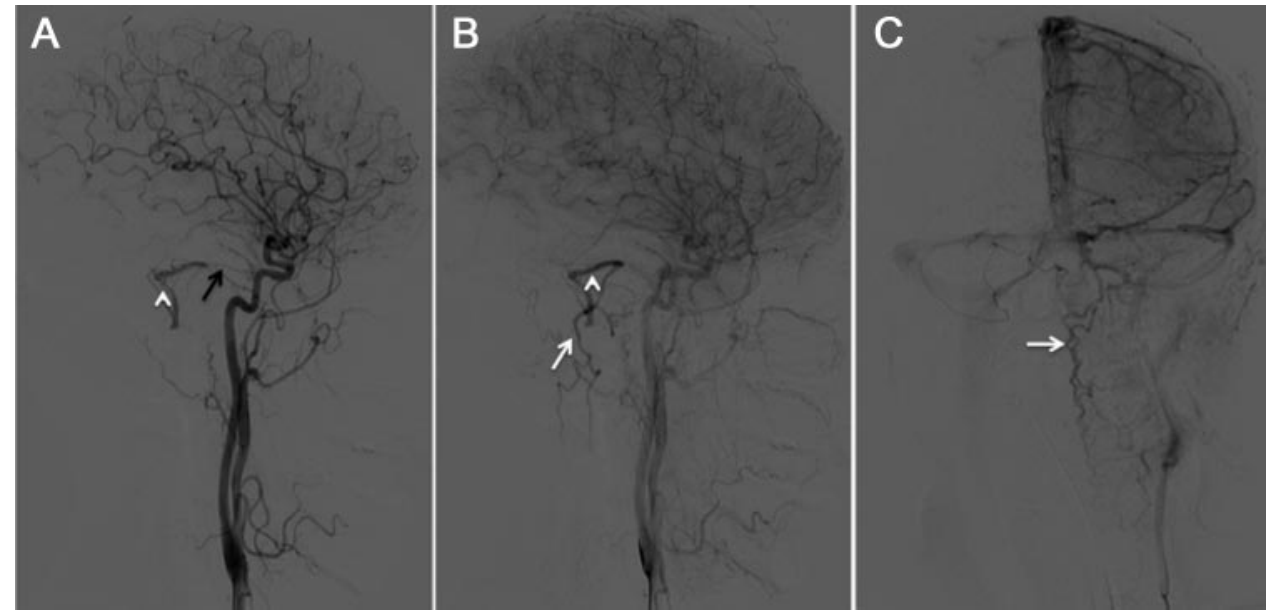

Angiogram demonstrates a dural arteriovenous fistula supplied by the tentorial artery of meningohypophyseal trunk (black arrow, A) draining into a transcortical vein, occipital sinus (arrowhead, A, B), and epidural venous plexus (white arrows, B, C). 


\section{Neurology}

\section{Teaching NeuroImages: Intracranial dural arteriovenous fistula presenting as ascending paralysis}

Waldo R. Guerrero, Haitham Dababneh, James Cook, et al.

Neurology 2012;79; e5-e6

DOI 10.1212/WNL.0b013e31825dce4d

\section{This information is current as of July 2, 2012}

\section{Updated Information \&} Services

References

Subspecialty Collections

Permissions \& Licensing

Reprints including high resolution figures, can be found at: http://n.neurology.org/content/79/1/e5.full

This article cites 2 articles, 0 of which you can access for free at: http://n.neurology.org/content/79/1/e5.full\#ref-list-1

This article, along with others on similar topics, appears in the following collection(s):

\section{All Spinal Cord}

http://n.neurology.org/cgi/collection/all_spinal_cord Arteriovenous malformation

http://n.neurology.org/cgi/collection/arteriovenous_malformation Clinical neurology examination http://n.neurology.org/cgi/collection/clinical_neurology_examination CT

http://n.neurology.org/cgi/collection/ct

MRI

http://n.neurology.org/cgi/collection/mri

Information about reproducing this article in parts (figures,tables) or in its entirety can be found online at:

http://www.neurology.org/about/about_the_journal\#permissions

Information about ordering reprints can be found online: http://n.neurology.org/subscribers/advertise

Neurology ${ }^{\circledR}$ is the official journal of the American Academy of Neurology. Published continuously since 1951, it is now a weekly with 48 issues per year. Copyright Copyright @ 2012 by AAN Enterprises, Inc.. All rights reserved. Print ISSN: 0028-3878. Online ISSN: 1526-632X.

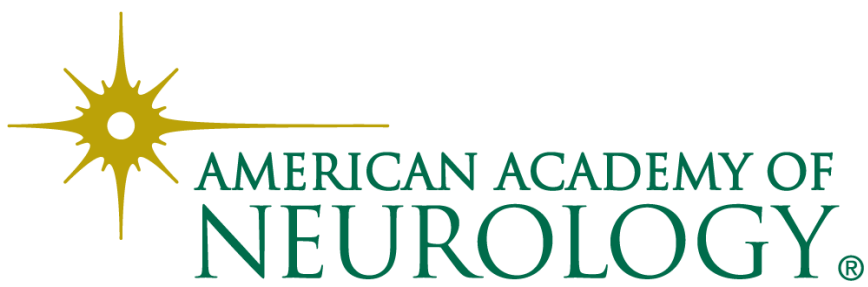

